\title{
Nitrite Poisoning of Fish in Aquaculture Facilities with Water-recirculating Systems
}

\author{
Z. SVOBODOVÁ ${ }^{1,2}$, J. MÁCHOVÁ ${ }^{1}$, G. POLESZCZUK ${ }^{3}$, J. HŮDA $^{4}$, \\ J. HAMÁČKOVÁ ${ }^{1}$, H. KROUPOVÁ ${ }^{1}$ \\ ${ }^{1}$ University of South Bohemia in České Budějovice, Research Institute of Fish Culture and Hydrobiology, \\ Vodňany, Czech Republic \\ ${ }^{2}$ University of Veterinary and Pharmaceutical Science, Brno, Czech Republic \\ ${ }^{3}$ Szczecin University, Szczecin, Poland \\ ${ }^{4}$ Fishery Třeboň, Czech Republic
}

Received August 23, 2004

Accepted March 3, 2005

\begin{abstract}
Svobodová, Z., J. Máchová, G. Poleszczuk, J. Hůda, J. Hamáčková, H. Kroupová: Nitrite Poisoning of Fish in Aquaculture Facilities with Water-recirculating Systems. Acta Vet Brno 2005, 74: 129-137.

Three cases of severely compromised fish health and death in newly commissioned aquaculture facilities with water-recirculating systems are described. The cause of the damage and death was increased concentrations of water-borne nitrites and the subsequent methaemoglobinemia. The aim of the study was to better understand the aetiology of these cases of poisoning to help prevent them, and to examine effects of some water quality parameters on nitrite toxicity. The increased $\mathrm{NO}_{2}{ }^{-}$concentrations in water were caused by impaired functionality of biological filters in the second stage of nitrification, i.e. the conversion of $\mathrm{NO}_{2}{ }^{-}$to $\mathrm{NO}_{3}{ }^{-}$. Chloride concentrations in water were considered the main factor influencing $\mathrm{NO}_{2}$ - toxicity in all of the cases described. In the case of death of catfish and tench, the $\mathrm{Cl}^{-}$to $\mathrm{N}_{-} \mathrm{NO}_{2}{ }^{-}$weight ratios were in the range of $13-28$ and 11 19 , respectively. In the case of tilapia health impairment without symptoms of toxicity, the ratios were between 50 and 150 . In the water tank inflow, the $\mathrm{Cl}^{-}$to $\mathrm{N}-\mathrm{NO}_{2}^{-}$weight ratios were between 2000 and 10000. Blood methaemoglobin levels of catfish and tench (severe symptoms of poisoning) and of tilapia (no signs of impairment, only brownish discolouration of gills) were over $80 \%$ and $21 \%$, respectively). In order to minimize risks in culture of fish in water-recirculating systems, it is necessary to choose a proper stock of fish and a proper feeding ratio, not to treat the fish with antibiotics in the form of baths, to check meticulously the quality of water. In case of increasing concentration of nitrites, to administer sodium chloride to get the chloride concentration increased at least to $100 \mathrm{mg} \cdot 1^{-1} \mathrm{Cl}^{-}$. Better operation of a biological filter can be speeded up by inoculation with activated sludge.
\end{abstract}

Methaemoglobinemia, $\mathrm{Cl}^{-}$to $\mathrm{N}-\mathrm{NO}_{2}^{-}$weight ratio, Silurus glanis L., Tinca tinca L., Oreochromis niloticus, biological filters, nitrification

The increasing need for growing fish under controlled conditions coupled with limited capacity of water resources has led to the building of aquaculture facilities where up to $95 \%$ of water is being recirculated. The main product of protein metabolism of fish, i.e. ammonia (Lloyd 1992; Wood 1993; S mutná et al. 2002) is removed from the tanks by nitrification (conversion to nitrites and subsequently to nitrates) by means of biofilters. Imbalances of the nitrification process, which might be due to a number of factors, will, however, often lead to an increase in the nitrite concentrations.

Nitrite toxicity to fish varies considerably and depends on a large number of external and internal factors. Among the most important ones are water quality (Craw ford and Allen 1977; Russo et al. 1981; Eddy et al. 1983; Lewis and Morris 1986; Bartlett and Neumann 1998), fish species (Palachek and Tomasso 1984; Lewis and Morris 1986), fish size (Bartlett and Neumann 1998), and individual fish susceptibility 
(Williams and Eddy 1988; Stormer et al. 1996; Aggergaard and Jensen 2001). The importance of these and other factors is constantly being assessed and re-evaluated. Different authors reach sometimes even contradictory conclusions, and no final explanation of the combined effect of individual internal and external factors on nitrite toxicity to fish has been put forward (Lew is and Morris 1986; Meinelt et al. 1997; Jensen 2003). On the other hand there is no doubt that chloride concentrations in water are mentioned most frequently as one of the most important factors influencing nitrite toxicity to fish (Russo and Thurston 1977; Jensen 2003).

In 2000, the authors of this paper investigated two cases diagnosed as nitrite poisoning which resulted in the death of the fish in aquaculture rearing tanks with water-recirculating systems, and another case in 2003 of damage to fish in a newly built aquaculture tank with water-recirculating system as a result of high nitrite concentrations. This paper is an analysis of the cases and their results. The aim of the study was to better understand the genesis, aetiology and prevention of fish poisoning, and to test the effects of some water quality parameters on nitrite toxicity.

\section{Death of catfish in a newly commissioned aquaculture facility with water-recirculating system in 2000}

\section{Case history}

Three thousand catfish (Silurus glanis L.) weighing between 300 and $500 \mathrm{~g}$ were placed to a newly-built aquaculture tank, which corresponded to its design capacity . Gradually dying fish were found there about ten days later. The gills of dead catfish had a brownish colour. Water oxygen levels in the tank were around $12 \mathrm{mg} \cdot l^{-1}$, water temperature was $24^{\circ} \mathrm{C}$. Samples of water and fish from the tank were delivered to the Research Institute of Fish Culture and Hydrobiology of the South Bohemia University at Vodňany on May 25, 2000.

Examination of fish

Six catfish weighing from 300 to $500 \mathrm{~g}$ were delivered for examination. The fish were brought alive, and under oxygen atmosphere. The condition of four of the fish was examined. Their skin was rather dark, with numerous depigmented spots along the sides of the body. The eyes showed no changes. The gills had a brownish colour. Vessels in body cavities were dilated. No parasites on the skin, gills or internal organs were found. Also negative were results of virological and bacteriological tests made by the State Veterinary Institute České Budějovice. Two of the catfish were put to the fish tank of University of South Bohemia in České Budějovice, Research Institute of Fish Culture and Hydrobiology, Vodňany. The fish showed no signs of damage and it was assumed that the four-hour transport in oxygen atmosphere had positively influenced their recovery.

Analyses of water

Physical and chemical properties of water samples collected from the water main meet the water quality specifications for aquaculture. Water samples collected from the biofilter and the tank showed high levels of total ammonia (no toxic $\mathrm{NH}_{3}$ was present thanks to low $\mathrm{pH}$ levels). High concentrations of nitrites and increased values of $\mathrm{COD}_{\mathrm{Mn}}$ were also found. Weight and molar ratios between chloride and nitrite concentrations in biofilter and tank samples were very low (Table 1).

On-site examination of fish on May 25, 2000

The fish in the aquaculture tank with water-recirculating system continued to die. The gills of all the catfish had a brown to deep rusty brown colour. Blood of five catfish was tested for methaemoglobin. The colour of the blood was brownish to rusty. Haematological examinations (Svobodová et al. 1991) showed $87 \pm 11 \%$ of methaemoglobin. The fish were then transferred to a tank outside the water-recirculating system where water quality 
corresponded to the quality of sample 1 - the water main. The fish there, however, continued to die. In the end, only about a quarter of the original stock, were saved.

Table 1. Physical and chemical properties of water in the aquaculture tank with water-recirculating system

\begin{tabular}{|c|c|c|c|}
\hline & $\begin{array}{c}\text { Water main supplying the } \\
\text { aquaculture tank }\end{array}$ & Biofilter & Rearing tank \\
\hline $\mathrm{pH}$ & 7.39 & 6.38 & 6.04 \\
\hline $\mathrm{KNK}_{4,5}\left(\mathrm{mmol} \cdot 1^{-1}\right)$ & 0.85 & 1.15 & 0.70 \\
\hline $\mathrm{ZNK}_{8,3}\left(\mathrm{mmol} \cdot \mathrm{l}^{-1}\right)$ & 0.03 & 0.70 & 0.40 \\
\hline $\operatorname{COD}\left(\mathrm{mg} \cdot 1^{-1}\right)$ & 1.70 & 33.10 & 38.00 \\
\hline $\mathrm{NH}_{4}^{+}+\mathrm{NH}_{3}\left(\mathrm{mg} \cdot 1^{-1}\right)$ & 0.012 & 4.86 & 5.35 \\
\hline $\mathrm{NO}_{2}^{-}\left(\mathrm{mg} \cdot 1^{-1}\right)$ & 0.003 & 2.75 & 1.60 \\
\hline $\mathrm{NO}_{3}^{-}\left(\mathrm{mg} \cdot 1^{-1}\right)$ & 4.78 & 7.71 & 16.57 \\
\hline $\mathrm{CI}^{-}\left(\mathrm{mg} \cdot 1^{-1}\right)$ & 9.20 & 11.00 & 13.50 \\
\hline \multicolumn{4}{|l|}{ Weight ratio } \\
\hline $\mathrm{CI}^{-}: \mathrm{N}-\mathrm{NO}_{2}^{-}$ & 10110 & 13.45 & 27.55 \\
\hline $\mathrm{CI}^{-}: \mathrm{NO}_{2}^{-}$ & 3067 & 4.11 & 8.44 \\
\hline \multicolumn{4}{|l|}{ Molar ratio } \\
\hline $\mathrm{Cl}^{-}: \mathrm{NO}_{2}^{-}$ & 3714 & 5.17 & 13.0 \\
\hline
\end{tabular}

\section{Diagnosis}

The death of catfish in the new aquaculture facility with water-recirculating system was caused by a high concentration of water-borne nitrates (and at the same time low weight and/or molar ratios between $\mathrm{Cl}^{-}$and $\mathrm{NO}_{2}^{-}$) and subsequent methaemoglobinemia. That occurred because too many fish were put in the tank and the efficacy of biofilters (particularly in the 2nd stage of nitrification, i.e. $\mathrm{NO}_{2}{ }^{-}$oxidation to $\mathrm{NO}_{3}{ }^{-}$) was inadequate.

\section{Death of tench in a re-comissioned experimental aquaculture facility with water-recirculating system in $\mathbf{2 0 0 0}$}

Case history

In early December 2000, 4-year old tench (Tinca tinca L.) weighing $400-1000 \mathrm{~g}$ were shipped from hatcheries (water temperature $4{ }^{\circ} \mathrm{C}$ ) to an aquaculture facility with a waterrecirculating system. The operation of that experimental aquaculture facility had been halted about six months earlier and it was just being re-commissioned at that time. After the tench were placed to the tank, water temperature in the recirculating system was gradually increased to $20^{\circ} \mathrm{C}$. Oxygen concentrations were between 7.3 and $8.6 \mathrm{mg} \cdot \mathrm{l}^{-1}$. On December 13, a part of the tench stock in the facility died.

\section{Examination of fish}

The tench were lethargic; when captured, muscle tissue convulsions and even cramps were observed. The gills were dirty dark brown in colour, the body cavity had a lighter colour, the liver, kidney and outflowing blood, which was not haemolytic, were dirty brown in colour. On December 13, blood samples of six tench with severe symptoms of poisoning (lateral position, muscle tissue cramps, dark brown gills) were collected by cardial puncture, and on December 14, blood samples of another five tench with symptoms of damage (lethargy, normal position, brownish gills) were collected. Methaemoglobin levels in tench with severe symptoms of poisoning and mild symptoms of damage were $82.7 \pm 7.04 \%$ and $63.1 \pm 13.56 \%$, respectively. The results show that most haemoglobin has oxidized to methaemoglobin in both tench with severe symptoms of poisoning and tench with damage symptoms only. 
Analyses of water

Results of physical and chemical of water analyses are in Table 2. Parameters of the water supplied to the water-recirculating system meet the quality standards for water used for aquaculture purposes. Water samples collected from fish farming tanks showed high ammonia levels (the sample collected on December 13 did not contain any of the toxic form; the sample taken on December 16 contained $0.04 \mathrm{mg} \cdot \mathrm{l}^{-1} \mathrm{NH}_{3}$ ) and, most importantly, high nitrite levels. Weight and molar ratios between chloride and nitrite concentrations in rearing tank water samples were very low.

Table 2. Physical and chemical properties of water at the inflow to the water-recirculating system in the tench experimental rearing tank

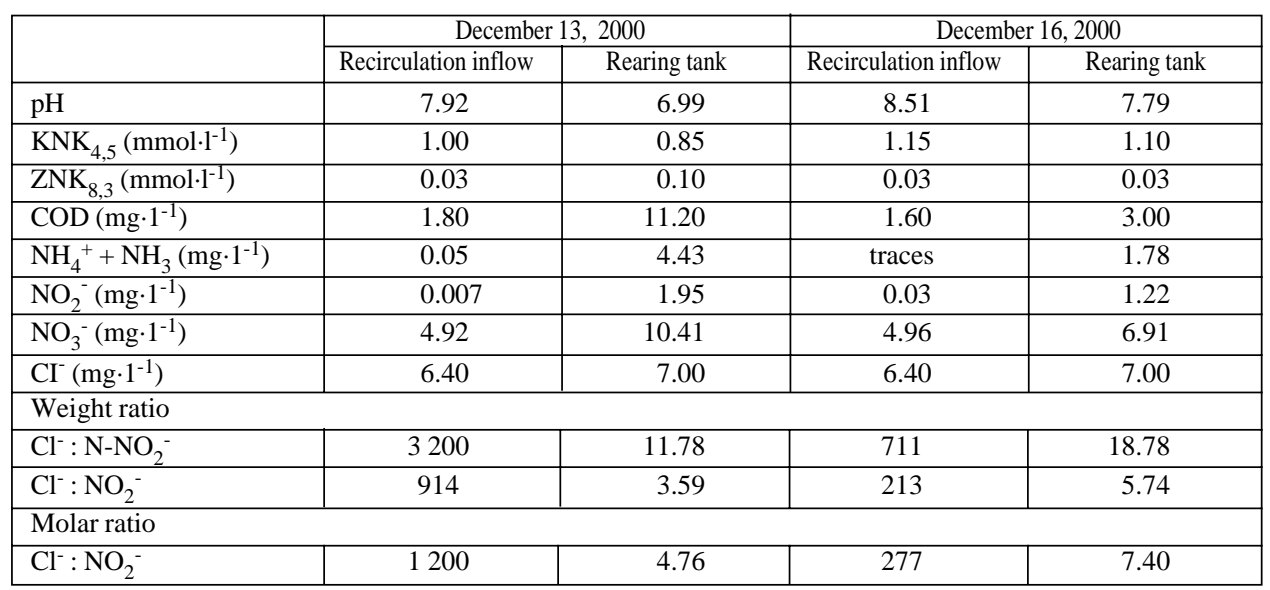

\section{Diagnosis}

The death of catfish in the re-commissioned experimental aquaculture facility was caused by a high concentration of nitrites (and at the same time low weight and molar ratios between $\mathrm{Cl}^{-}$and $\mathrm{NO}_{2}^{-}$in the rearing tank water) and subsequent methaemoglobinemia. The cause of that was inadequate efficacy of biofilters (particularly in the 2nd stage of nitrification, i.e. $\mathrm{NO}_{2}^{-}$oxidation to $\mathrm{NO}_{3}^{-}$).

\section{Damage to tilapias in a newly commissioned aquaculture facility with a water-recirculating system in 2003}

\section{Case history}

In June 2003, a new water-recirculating system was put into operation in the absence of fish. In mid July, tilapias (Oreochromis niloticus) were introduced to the facility with a water-recirculating system. In early August (August 8, 2003), deterioration of fish health was observed. For that reason, feed rations were reduced from originally $3.5 \mathrm{~kg}$ to $2 \mathrm{~kg}$. Water analysis from August 11, 2003 demonstrated extremely high ammonia nitrogen levels (practically no ammonia in the toxic, i.e. undissociated form was present due to low $\mathrm{pH}$ values) and elevated nitrate concentrations (Table 3). Water saturation with oxygen in different tanks ranged from 40 to $70 \%$.

\section{Examination of fish}

On August 11, eleven tilapias weighing between 133 and $282 \mathrm{~g}$ were examined. Parasitological tests were negative. The gills the fish were brownish in colour, their guts partly filled with feed and the livers had brittle consistency. Blood methaemoglobin levels 
ranged between 11 and 26\% $(21 \pm 4.5 \%)$. On the next day (August 12) the condition and behaviour of the fish were the same as the day before. Their gills still had a slightly brownish colour. Two tanks with the biggest water oxygen saturation difference ( $43 \%$ and $70 \%)$ were selected. Five tilapias were taken out of each of the tanks and their blood methaemoglobin concentrations were determined. Methaemoglobin levels found in the fish from the two tanks were comparable (11 and 10\%). Their levels, were, however, halved compared with methaemoglobin concentrations ascertained in the tests on August 11. In the period that followed, the fish condition gradually improved. Starting on August 18, the fish began to feed readily and their gills had a bright red colour. The situation stabilized the following week. The aquaculture operation continued smoothly.

Table 3. Physical and chemical parameters of rearing tank water

\begin{tabular}{|l|c|c|c|c|c|c|c|}
\hline \multirow{2}{*}{$\begin{array}{l}\text { Date } \\
\text { of testing }\end{array}$} & \multirow{2}{*}{$\mathrm{pH}$} & $\mathrm{NH}_{4}^{+}$ & $\mathrm{NO}_{2}^{-}$ & $\mathrm{CI}^{-}$ & \multicolumn{2}{c|}{ Weight ratio } & Molar ratio \\
\cline { 3 - 8 } & & \multicolumn{3}{|c|}{$\mathrm{mg} \cdot l^{-1}$} & $\mathrm{Cl}^{-} \mathrm{N}_{-} \mathrm{NO}_{2}^{-}$ & $\mathrm{Cl}^{-}: \mathrm{NO}_{2}^{-}$ & $\mathrm{Cl}^{-}: \mathrm{NO}_{2}^{-}$ \\
\hline August 11 & 5.50 & 24.99 & 0.76 & 35.0 & 151 & 46 & 58.8 \\
\hline August 12 & 6.50 & 25.24 & 1.30 & 36.1 & 91.2 & 27.8 & 36.8 \\
\hline August 13 & & 23.69 & 2.00 & 166 & 273 & 83 & $\left.110^{*}\right)$ \\
\hline August 14 & & 22.80 & 0.40 & 144 & 1170 & 360 & 472 \\
\hline August 15 & 5.41 & 24.47 & 0.19 & 130 & 2241 & 684 & 905 \\
\hline
\end{tabular}

*) $\mathrm{NaCl}$ applied

\section{Analyses of water}

Results of tests of water analysis from the rearing tank over the monitoring period are in Table 3.

Low $\mathrm{pH}$ and high ammonia concentrations (ammonia was present only in the dissociated form $\mathrm{NH}_{4}^{+}$) in the rearing tank water were recorded over the entire period of monitoring. To respond to increasing nitrite concentrations, common salt was added to the recirculation system on August 13 to increase the chloride concentrations. To enhance the biological filter function, activated sludge from a waste-water treatment plant was added. The next day (August 14), some more mains water was added to the water-recirculating system. That led to a decrease in chloride, and even more, nitrite concentrations. Ammonia levels remained very high. On August 15, a marked decrease in water-borne nitrite concentrations was observed, while ammonia concentrations remained very high. The next week, the situation stabilized and the ammonia concentration decreased to $0.37 \mathrm{mg} \cdot \mathrm{l}^{-1}$. At the beginning of monitoring, the weight and molar ratios between chlorides and nitrites were very low. The ratios increased after $\mathrm{NaCl}$ was added to water, and they further increased significantly following the decrease in recirculation water nitrite concentrations.

Diagnosis

Health damage to tilapias in the new experimental aquaculture facility with a waterrecirculating system was caused by excessive water-borne nitrite concentrations and the subsequent increase in methaemoglobin levels. The cause of that was the temporarily inadequate efficacy of biofilters (in this case in both the 1st and 2nd stages of nitrification, i.e. ammonia oxidation to $\mathrm{NO}_{2}^{-}$and $\mathrm{NO}_{2}^{-}$oxidation to $\mathrm{NO}_{3}^{-}$).

\section{Discussion}

Final products of protein metabolism in freshwater fish are ammonia (90\%) and urea $(10 \%)$ (Pequin and Serfaty $1966 \mathrm{ab}$ ). In its nonionized (molecular) form, ammonia is highly toxic to fish (Warren 1962). For that reason, closed water-recirculating systems 
need to be able to convert the toxic products to low-toxic nitrates. The conversion takes place in biofilters in two stages, the first is the conversion of ammonia to nitrites and then the conversion of nitrites to nitrates. In all the three cases described here, insufficient efficacy of biofilters was observed, which led to poor nitrification performance, particularly in its second stage. The resulting increased concentrations of water-borne nitrites caused damage to and death of fish due to methaemoglobinemia.

Chloride concentrations in water were considered the main factor influencing nitrite toxicity to fish in all three cases investigated. The fact that nitrite toxicity is strongly dependent on water salinity was first reported in 1977 (Craw ford and Allen 1977). At the same nitrite levels, fish mortality in saltwater was found to be 50 to 100 times lower than fish mortality in freshwater. The effect of chlorides on nitrite toxicity is so big that experiments in which water-borne chloride concentrations were not ascertained lose most of their relevance because they cannot be compared with results of any other studies. Rus so and Thurst on (1977) demonstrated a linear relationship between nitrite toxicity and waterborne chloride concentrations.

The problem with nitrites in freshwater is due to the fact that $\mathrm{NO}_{2}^{-}$demonstrates a degree of affinity to the $\mathrm{Cl}^{-} / \mathrm{HCO}_{3}^{-}$ion exchange. In the presence of nitrites in the surrounding water, a part of the $\mathrm{Cl}^{-}$uptake is replaced with $\mathrm{NO}_{2}^{-}$(i.e. the fish absorb nitrites at the expense of chlorides). The chlorides/nitrites replacement theory has further been corroborated by the finding that fish with rapid intake of chlorides through gills (rainbow trout, perch, pike) were more susceptible to nitrites that fish with slow rates of chloride intake (eels, carp, tench) (Williams and Eddy 1986). These facts also explain why increased $\mathrm{Cl}^{-}$concentrations in the immediate environment provide protection to fish against the intake of nitrites and their toxic effects (Jensen 2003). The protective effect of chlorides was also observed in the incident described above involving damage to tilapias (2003). The tilapias survived exposure to $2 \mathrm{mg} \cdot \mathrm{l}^{-1}$ nitrites at the chloride concentration of $166 \mathrm{mg} \cdot \mathrm{l}^{-1}$ without any marked changes to their condition (red gills).

It follows from the above cases and literary data that chloride concentrations in water need to be raised if fish in aquaculture facilities are under the threat of damage by nitrites. This preventive measure is used by aquarists in aquariums where levels of nitrogenous metabolites rise as a result of insufficient water renewal. Experienced and observant aquarists add salt to water to protect some fish species (e.g. Poecilia sphenops) against damage by nitrites (Dvořák 2004).

The question of the value of the weight (or molar) ratios between chlorides and nitrites in aquaculture water remains unanswered. EIFAC materials (1984) recommend that $\mathrm{Cl}^{-}: \mathrm{N}-\mathrm{NO}_{2}^{-}$weight ratio be monitored in water. The ratios the material recommends for rainbow trout and for cyprinid species are 17 and 8 , respectively. In aquaculture facilities with water-recirculating systems where death of catfish and tench reported here occurred, these ratios were 13.45 and 27.55 (catfish) and 11.78 and 18.78 (tench). In the recirculating system supplying water, the ratios were 10110 (catfish) and 3200 and 711 (tench). In the last incident described that involved health damage to tilapias, the $\mathrm{Cl}^{-}: \mathrm{N}_{-} \mathrm{NO}_{2}^{-}$ratio was approximately $90-150$. In the period that followed when their condition gradually improved, the same ratio was between 270 and 2240. It is clear from the results reported here and the ensuing discussion that the EIFAC parameters proposed as the optimum values are in need of a re-evaluation. Results of the present study indicate that the $\mathrm{Cl}^{-}: \mathrm{N}_{-} \mathrm{NO}_{2}^{-}$ratio in aquaculture water is markedly higher than proposed in EIFAC materials (1984). It would, however, be premature to generalize the results reported here. More monitoring and experimental efforts will be needed before more general conclusions can be drawn. Moreover, it can be assumed that different ratios will apply depending on different species and age of fish and physical and chemical parameters of the aqueous environment. 
It is not really important whether the $\mathrm{Cl}^{-}: \mathrm{N}_{-} \mathrm{NO}_{2}^{-}$or the $\mathrm{Cl}^{-}: \mathrm{NO}_{2}^{-}$weight ratios are used, or whether the $\mathrm{Cl}^{-}: \mathrm{NO}_{2}$ molar ratio is used instead. The really important thing is to ensure that results of studies are compatible. In the future, however, the use of the $\mathrm{Cl}^{-}: \mathrm{NO}_{2}^{-}$molar ratio might prove more straightforward than the use of weight ratios because it would prevent possible confusion whether the $\mathrm{Cl}^{-}: \mathrm{N}-\mathrm{NO}_{2}^{-}$or the $\mathrm{Cl}^{-}: \mathrm{NO}_{2}^{-}$ratios are being used.

The inhibitory effect of oxygen on nitrite toxicity in fish was demonstrated during the transport of six catfish in 2000 in bags with high-oxygen atmosphere. Oxygen concentration may influence nitrite toxicity. Nitrites reduce the oxygen-transport capacity of blood. In their study with catfish, Bows er et al. (1983) demonstrated that oxygen concentration of $5 \mathrm{mg} \cdot \mathrm{l}^{-1}$ at the presence of nitrites was insufficient, although catfish are known to easily tolerate even lower concentrations. On the other hand, no effects of different levels of saturation of water with oxygen (43 and $70 \%$ at nitrite concentration of $1.30 \mathrm{mg} \cdot \mathrm{l}^{-1}$ ) on methaemoglobin levels in tilapias (in 2003). In this case, it can be assumed that $43 \%$ saturation of water with oxygen was sufficient for tilapias and comparable with the $70 \%$ saturation.

In the cases reported here, catfish and tench had high methaemoglobin concentrations. They were cases of severe nitrite poisoning with mortalities. Examination of catfish showed that $87 \pm 11 \%$ of haemoglobin had oxidized to methaemoglobin, i.e. in some of the fish practically all the haemoglobin had been converted to methaemoglobin. Tilapias showed no symptoms of poisoning at $21 \pm 4.5 \%$ methaemoglobin, their gills, however, had a brownish colour. Similar data were published in a review by Lewis and Morris (1986), who considered 50\% methaemoglobin as a critical level. According to these authors, $70-80 \%$ methaemoglobin in blood causes symptoms of poisoning, but fatalities occur only when the percentage of methaemoglobin rises even further. Contrary to fish, mammals already show symptoms of mild poisoning at $10-15 \%$ methaemoglobin in blood, and critical levels leading to CNS anoxia and death are at about $50-60 \%$ methaemoglobin (Piskač et al. 1985; Vopršálová and Žáčková 2000).

\section{Conclusions}

To minimize the risk of fish mortality due to excessive nitrite concentrations in waterrecirculating systems, the following principles should be observed:

- new aquaculture facilities should be stocked gradually and their filter capacity observed in order to maintain the quality of water necessary for aquaculture purposes. Feed rations should be optimized in relation with the immediate status of the water-treatment unit. Tanks should be fully stocked only after biological filters can demonstrably operate at full capacity

- parameters that should be monitored continuously in the facility include oxygen, ammonia, nitrites, nitrates and chloride concentrations, and the chloride-to-nitrite weight or molar ratios

- if there is an upward trend in nitrite concentrations, the chloride concentration should be raised to at least $100 \mathrm{mg} \cdot \mathrm{l}^{-1}$ as a preventive measure

- the function of the biological filter can be restored by adding activated sludge from a well-operating waste-water treatment plant. The inoculum in its inactive form can also be obtained from reputable manufacturers of waste water treatment plants

- no antibiotics in the form of baths should be used in water-recirculating systems for the treatment of fish there in order to prevent any damage to the biological filter functionality.

\section{Otrava ryb dusitany v recirkulačních systémech}

V předkládané práci jsou prezentovány 3 případové studie poškození a úhynu ryb v rybochovných objektech s recirkulací uváděných do provozu. Příčinou poškození a úhynu ryb byla zvýšená koncentrace dusitanů ve vodě a následná methemoglobinemie. Cílem 
práce bylo přispět $\mathrm{k}$ etiologii a $\mathrm{k}$ prevenci těchto otrav a současně přispět $\mathrm{k}$ ověření účinků některých faktorů kvality vody na toxicitu dusitanů. Př́činou zvýšené koncentrace $\mathrm{NO}_{2}^{-}$ve vodě byla omezená funkce biologických filtrů ve druhé fázi nitrifikace, tj. př̌eměny $\mathrm{NO}_{2}^{-}$na $\mathrm{NO}_{3}^{-}$. Jako hlavní faktor ovlivňující toxicitu $\mathrm{NO}_{2}^{-}$byla ve všech př́ípadech vzata do úvahy koncentrace chloridů ve vodě. Hmotnostní poměr $\mathrm{Cl}^{-}$a N-NO v rozmezí $13-28$, línů $11-19$. $V$ prrípadě poškození zdravotního stavu tilapií bez příznaků otravy byl tento poměr v rozmezí 50 - 150 . V př́tokové vodě do objektů se hmotnostní poměr $\mathrm{Cl}^{-}$a N-NO- pohyboval v rozmezí 2000 až 10 000. Zastoupení methemoglobinu v krvi bylo v př́ipadě sumců a línů se silnými příznaky otravy nad $80 \%$, v príípadě tilapií $21 \%$ (bez př́iznaků poškození, pouze nahnědlá barva žaber). $\mathrm{K}$ minimalizaci rizik v chovech ryb $\mathrm{v}$ recirkulačních systémech je třeba volit vhodnou obsádku ryb a krmné dávky, $\mathrm{k}$ léčbě ryb nepoužívat antibiotika ve formě koupelí, důsledně kontrolovat kvalitu vody a při nárůstu koncentrace dusitanů dávkovat chlorid sodný pro zvýšení koncentrace chloridů na hodnotu min. $100 \mathrm{mg} \cdot l^{-1} \mathrm{Cl}^{-}$. Zapracování biologického filtru je možno urychlit inokulací aktivovaným kalem.

\section{Acknowledgements}

This research was supported by the Ministry of Education, Youth and Sports of the Czech Republic (MSM Project No. 6007665809)

\section{References}

AGGERGAARD, S, JENSEN, FB 2001: Cardiovascular changes and physiological response during nitrite exposure in rainbow trout. J Fish Biol 59: 13-27

BARTLETT, F, NEUMANN, D 1998: Sensitivity of brown trout alevins (Salmo trutta L.) to nitrite at different chloride concentrations. Bull Environ Contam Toxicol 60: 340-346

BOWSER, PR, FALLS, WW, VANZANDT, J, COLLIER, N, PHILLIPS, JD 1983: Methaemoglobinemia in channel catfish: methods of prevention. Prog Fish-Cult 45: 154-158

CRAWFORD, RE, ALLEN, GH 1977: Seawater inhibition of nitrite toxicity to chinook salmon. Trans Amer Fish Soc 106: 105-109

DVOŘÁK, P 2004. Vybraná specifika onemocnění akvarijních ryb (Selected specifity of aquarium fish diseases). In Czech. Bulletin VÚRH Vodňany 40: 101-108

EDDY, FB, KUNZLIK, PA, BATH, RN 1983: Uptake and loss of nitrite from the blood of rainbow trout, Salmo gairdneri Richardson, and Atlantic salmon, Salmo salar L. in fresh water and in dilute sea water. J Fish Biol 23: $105-116$

JENSEN, FB 2003: Nitrite disrupts multiple physiological functions in aquatic animals. Comp Biochem Physiol Part $A$ 135: 9-24

LEWIS, WM, MORRIS, DP 1986: Toxicity of nitrite to fish: a review: Trans Amer Fish Soc 115: 183-195

LLOYD, R 1992. Pollution and Freshwater Fish. Fishing New Books, 176 p.

MEINELT, T, SCHRECKENBACH, K, STUEBER, A, STEINBERG, C 1997: Fish toxicity of nitrite. Fisch Teichwirt 48: 421-426

PALACHEK, RM, TOMASSO, JR 1984: Toxicity of nitrite to channel catfish (Ictalurus punctatus), tilapia (Tilapia aurea), and largemouth bass (Micropterus salmoides): evidence for a nitrite exclusion mechanism. Can J Fish Aquat Sci 41:1739-1744

PEQUIN, L, SERFATY, A 1966a: Le role de la glutamine dans l'excrétion ammoniacale chez la carpe commune. J Physiol 58: 584-585

PEQUIN, L, SERFATY, A 1966b: Acide glutamique et excrétion azotée chez la carpe commune, Cyprinus carpio L. Comp Biochem Physiol 18:141-149

PISKAČ, A, BARTÍK, M, KAČMÁR, P, PROCHÁZKA, Z, SVOBODOVÁ, Z, ŠIKULA, J 1985: Veterinární toxikologie. SZN Praha, 254 p.

RUSSO, RC, THURSTON, RV, EMERSON, K 1981: Acute toxicity of nitrite to rainbow trout (Salmo gairdneri): effects of $\mathrm{pH}$, nitrite species, and anion species. Can J Fish Aquat Sci 38: 387-393

RUSSO, RC, THURSTON, RV 1977: The acute toxicity of nitrite to fishes. In: Tubb, RA (Ed.), Recent Advances in Fish Toxicity. EPA-600/3-77-085. US Environmental Protection Agency, Corvallis, OR, 118-131

SMUTNÁ, M, VORLOVÁ, L, SVOBODOVÁ, Z 2002: Pathobiochemistry of ammonia in the internal environment of fish (Review). Acta Vet Brno 71: 169-181

STORMER, J, JENSEN, FB, RANKIN, JC 1996: Uptake of nitrite, nitrate, and bromide in rainbow trout, Oncorhynchus mykiss: effects on ionic balance. Can J Fish Aquat Sci 53: 1943-1950 
SVOBODOVÁ, Z, PRAVDA, D, PALÁČKOVÁ, J 1991: Unified methods of haematological examination of fish. Research Institute of Fish Culture and Hydrobiology Vodňany. Methods No. 20, 31 p.

VOPRŠÁLOVÁ, M, ŽÁČKOVÁ, P 2000: Základy toxikologie pro farmaceuty. Karolinum Praha, 231 p.

WARREN, KS 1962: Ammonia toxicity and $\mathrm{pH}$. Nature. 195: 47-49

WILLIAMS, EM, EDDY, FB 1986: Chloride uptake in freshwater teleosts and its relationship to nitrite uptake and toxicity. J Comp Physiol B 156: 867-872

WILLIAMS, EM, EDDY, FB 1988: Anion transport, chloride cell number and nitrite-induced methaemoglobinaemia in rainbow trout (Salmo gairdneri) and carp (Cyprinus carpio). Aquat Toxicol 13: $29-42$

WOOD, CM 1993: Ammonia and urea metabolism and exretion. In: Evans, DH (Ed) Physiology of Fishes. CRC Press Boca Raton, pp. 379-425

Water quality criteria for European freshwater fish: Report on nitrite and freshwater fish. EIFAC Tech Paper, 1984, No. 43,19 p. 